\title{
赤外線放射温度計による大麻山の 斜面温暖帯の測定
}

\author{
黒瀬義孝 ・真木太一 \\ （四国農業試験場土地利用部作目立地研究室）
}

\author{
Measurement of Thermal Belt on the Slope of Mt. Osa \\ by using Infrared Thermometer \\ Yoshitaka KUROSE and Taichi MAKI \\ $\left(\begin{array}{c}\text { Laboratory of Crop Location, Land Utilization Division } \\ \text { Shikoku National Agricultural Experiment Station, } \\ \text { 2575, Ikano, Zentsuji, Kagawa 765, Japan }\end{array}\right)$
}

\section{1.はじめに}

ランドサット，NOAA，ひまわりなどの人工衛星およ びセンサーを搭載した航空機によるリモートセンシング が広く行なわれるようになり，同一時刻の広範囲の面的 情報が得られるようになった。乙の観測データのいくつ かは農業分野の研究にあ活用されている。例えば，ひま わりの赤外データと AMeDAS 気温との関係把握 (谷ら, 1984），ひまわりのデータによる冷害気象の解明（下蔵 ら，1982），土壤水分の推定 (Heilman and Moore, 1980），航空機MSSデー夕による地表面熱収支分布の 評価(川島，1986)，土壤含砂率の推定(石黒，1985） などが報告されている。

人工衛星のデータを用いた研究では, 観測データの分 解能の関係から大，中気象を対象にしたり，航空機のデ 一夕を用いた研究では，一定の時間間隔でとに測定する のが困難であるため，ある時刻のデータで経時的な現象 を代表する場合が多い。したがって，人工衛星などの観 測デー夕は局地気象レベルでの経時的な現象の解析には あまり向いていない。

著者らは放射熱解析装置を使用して，熱映像から局地 気象および微気象レベルでの温度分布の特性を解明する 研究を続けている。今回の観測では，山の斜面に形成さ れる温暖帯，冷気湖などについて，表面温度から解析を 試みた。

従来の斜面温暖帯の観測では，移動観測であ，定点観 測であ測器の設置やデータの読み取りのために多大な労

昭和 62 年 4 月 4 日 全国大会にて発表 昭和 62 年 7 月 20 日 受理
力が必要であり, また測定值は点のデータであるため, 観測した地点の代表性などの関係から，面のデータに置 き換えるには問題があった。

熱映像の温暖帯への適用例には，飛行機に熱画像解析 装置を搭載し，筑波山の斜面温暖帯の測定を行なったも のがあり，早朝 7 時における温暖帯を面的に詳細なパ夕 ーンでとらえた研究 (小林, 1979) がある。また，温暖帯 の形成と関係の深い斜面冷気流や冷気湖などの観測結果 は多数報告されており（鳥谷，1985；田中ら，1982）， 斜面冷気流や冷気湖などの発生機構むかなり解明されて きた(近藤，1982)。しかし，乙れらの現象は極めて局 地性の強い現象であり, 種々の気象条件, 地形条件につ いてのデータの集積はなおむ必要と考えられる。

そこで，熱映像を使った斜面温暖帯の観測と風速など の気象条件を結びつけた研究を行ない, 斜面温暖帯につ いて興味ある結果が得られたので，その概要を報告する。

\section{2. 観 測 地 域}

大麻山は北緯 $34^{\circ} 12^{\prime}$, 東経 $133^{\circ} 47^{\prime}$ 亿位置し, 香 川県の善通寺市, 琴平町, 高瀬町にまたがる標高 $616 \mathrm{~m}$ の山である。

Fig. 1 亿大麻山北斜面とその周辺の地形，および放射 熱解析装置の設置地点，気温，風速の観測地点を示す。

観測対象である大麻山北斜面は勾配が $10^{\circ} \sim 40^{\circ}$ の傾 斜を成している。標高 $220 \mathrm{~m}$ 以上では主として針葉樹で 占められ，主な樹木は樹高約 $10 \mathrm{~m}$ のアカマッである。 一方, 標高 $220 \mathrm{~m}$ 以下の斜面では樹木之牧草で覆われて おり，放牧区の違いによる牧草の草丈は $5 \sim 30 \mathrm{~cm}$ でそ れぞれ異なる。 


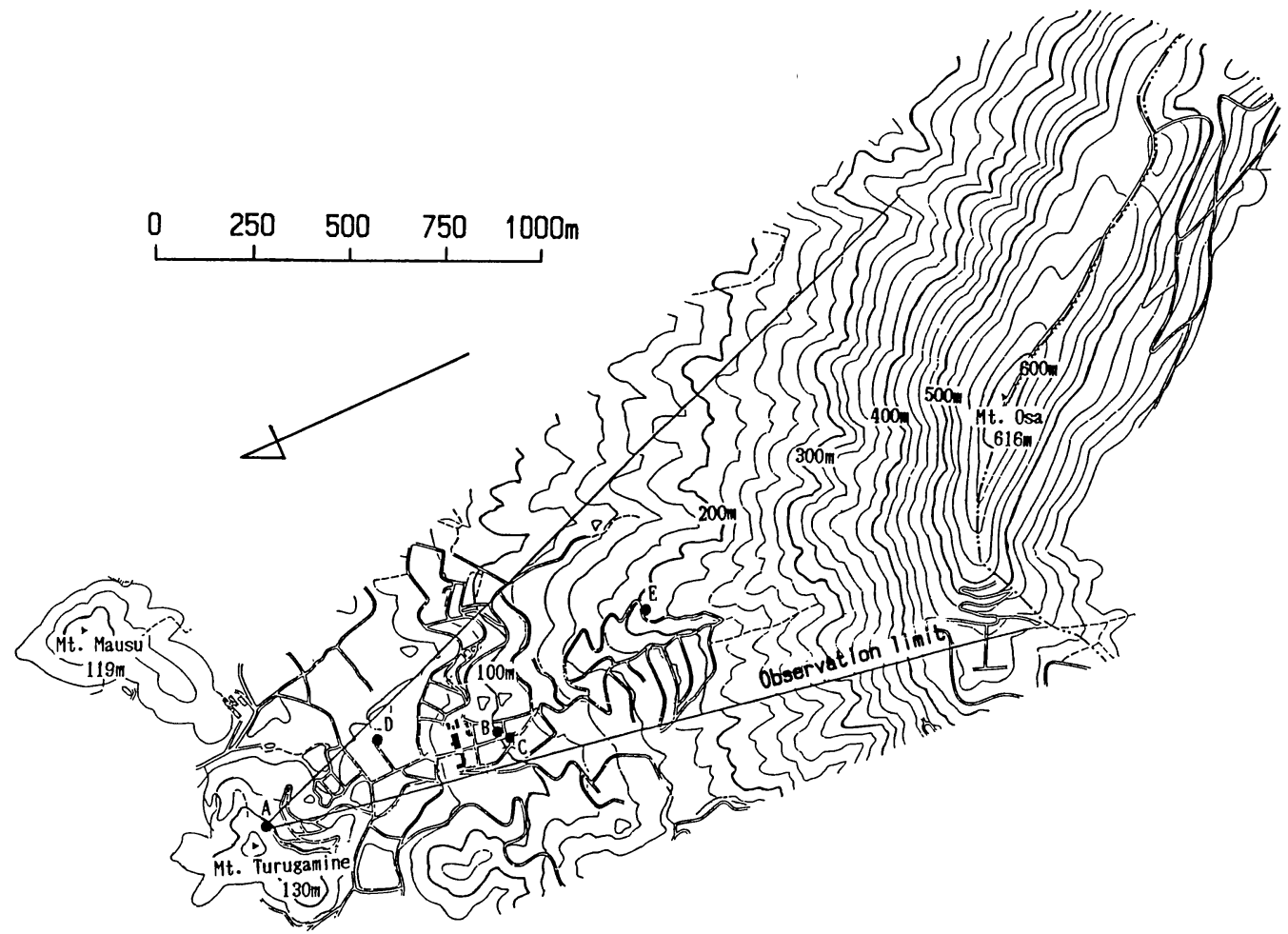

Fig. 1. Topographic map of observation area and its vicinity in Mt. Osa region. Notation of $\mathrm{A}-\mathrm{E}$ shows the observation points.

大麻山の北側には鶴ケ峰 $(130 \mathrm{~m})$ 之磨臼山 $(119 \mathrm{~m})$ が あり，標高 $110 \mathrm{~m}$ 以下ではこれらの山により開放度が小 さくなっている。

\section{3. 観測項目および観測方法}

\section{（1）熱映像}

観測対象の表面温度を表示・記録するために放射熱解 析装置 (日本電気三栄社製, サーモトレーサ6 T 61 型)を 使用した。

放射熱解析装置の使用赤外線波長は 8 13 $\mu \mathrm{m}$ で，い わゆる大気の空領域を使用しており，温度測定範囲は $-50 \sim 2000^{\circ} \mathrm{C}$ ，温度分解能は $0.1^{\circ} \mathrm{C}$ ( $30^{\circ} \mathrm{C}$ 黒体)，測定 視野は水平 $30^{\circ}$ ，垂直 $25^{\circ}$ の範囲であり， 1 画素の視野 角は $1.5 \mathrm{mrad}$ である。

自然物体の射出率は通常 1 より小さく，物体ごとに射 出率を設定して測定するか，射出率の違いによる誤差を 計算し補正する必要があるが，今回の観測では測定対象 物の射出率は 1 と仮定して測定を行なった。射出率の違 いによる放射温度と真の表面温度の関係を，真木・黒瀬 （1987）之同様に Fuchs and Tanner, （1966）の方法 で求めてみると, 物体の射出率を 0.95 とすると真の表
面温度と放射温度の温度差は $1^{\circ} \mathrm{C}$ 程度である。樹木, 牧 草の射出率は 0.97 以上であるため, 射出率による誤差は $0.6^{\circ} \mathrm{C}$ 程度であると考えられる。ただし，観測は冬季の 晴天夜間に行なわれたもので，周囲から対象物体への入 放射エネルギー量は $250 \mathrm{~W} / \mathrm{m}^{2}$ 程度と考えた。

また，測定対象物からセンサーまでの伝播経路中にお ける吸収，散乱による放射温度の低下の影響も考慮しな くてはならない。対象物を海面とし，高度による放射温 度の低下量の研究であるが，冬季では $0.9 \sim 1.5^{\circ} \mathrm{C} / \mathrm{km}$ と いう報告がある。今回の観測では低下量がどの程度かは 測定していないが，標高 $250 \mathrm{~m}$ 付近までは測定対象物ま での距離が長くなるにあかかわらず，温度は上昇してい るととから明らかに温暖帯が存在していると考えられ る。

大麻山北斜面を観測するために，放射熱解析装置を大 麻山の北側に位置する鶴ヶ峰の標高 $100 \mathrm{~m}$ 地点 (A) 亿設 置した。観測地点から測定対象物までの距離は $0.2 \sim 2.2$ $\mathrm{km}$ であり， 1 画素の大きさは $0.5 \sim 25.5 \mathrm{~m}^{2}$ である。樹 木, 牧草は密に繁茂しているため幹や土㙵の温度はほと んど含まれないと考えられる。

測定対象物は表面温度に対応してカラー表示されるが， 
処理の必要に応じて温度をデジタル表示させ読み取っ た。表面温度は樹木, 牧草が広く繁茂している場所を選 び，標高 $250 \mathrm{~m}$ 以上では $50 \mathrm{~m}$ 毎に，標高 $210 \mathrm{~m}$ 以下で は $20 \mathrm{~m}$ 毎に，各々の標高に扔いて数画素のデータから 求めた。

熱映像の観測は，1986 年 12 月 2 6 日，1987 年 2 月 23〜25日，4月 13〜15日の 3 回行なった。熱映像の測 定間隔は，12月と 2 月の観測では 15 分毎，4 月の観測 では 20 分毎である。

なお，観測したデー夕は表面温度であるのに対し，斜 面温暖帯は接地気層内の気温に関する現象の用語である が，適当な用語がないためそのまま使用した。また，山 の山麓の表面温度が中腹よりも低くなる現象についても, 同様な理由により逆転域という用語を使用した。

\section{(2) 気 温}

気温は，2 月と 4 月では大麻山北斜面の標高 $100 \mathrm{~m}$ 地 点 (B) の 5 高度 $(4,3,2,1,0.5 \mathrm{~m})$ で測定した。温度 計には白金抵抗体を使用し，連続測定を行なった。測定 地点は草丈約 $40 \mathrm{~cm}$ の雑草で覆われた約 $10^{\circ}$ の傾斜地で あり，周囲は放牧地である。

12 月の気温データには, 標高 $106 \mathrm{~m}$ 地点 (C) の総合 気象観測装置による地上 $1 \mathrm{~m}$ 高の值を使用した。なお， 総合気象観測露場は， 2 月と 4 月の気温観測地点 (B) と は約 $30 \mathrm{~m}$ 離れているが，気象条件，地形条件に大きな 違いはない。

\section{（3）風向，風速}

2 月と 4 月では, 気温測定地点と同一地点 (B)で風向, 風速を測定した。風速測定は微風用 3 杯式風速計を用い て 4，3，2，1，0.5 mの 5 高度で，また風向測定は微風用 矢羽式風向計を用いて地上 $2 \mathrm{~m}$ 高で害施した。なお，標 高 $65 \mathrm{~m}$ 地点（D）に扔いて屯，地上 $1 \mathrm{~m}$ 高の風速を微風 用 3 杯式風速計を用いて連続測定した。

12 月の観測では，標高 $210 \mathrm{~m}$ 地点 $(\mathrm{E})$ で， 6, 4, 2.5, $1.5,0.8 \mathrm{~m}$ の 5 高度で風速を， $4 \mathrm{~m}$ の高度で風向を測定 した。また，標高 $106 \mathrm{~m}$ 地点 (C) にある総合気象観測装 置の地上 $10 \mathrm{~m}$ 高のエーロベーンによる風向, 風速デー 夕む使用した。

\section{4. 観測結果および考察}

\section{（1）気温亡表面葉温の関係}

Fig. 2 亿標高 $100 \mathrm{~m}$ 地点の気温と表面温度（測定した 箇所が樹木で覆われているため，以下葉温）の関係を示 す。日射の影響がない夜間の気温之葉温は比較的高い相 関 (相関係数： $r=0.90)$ が認められた。

4 月の観測では葉温>気温の関係が得られたが，ての 主な原因は, 気温 ( $4 \mathrm{~m}$ 高) 之葉温 (約 $10 \mathrm{~m}$ 高)の測定高度

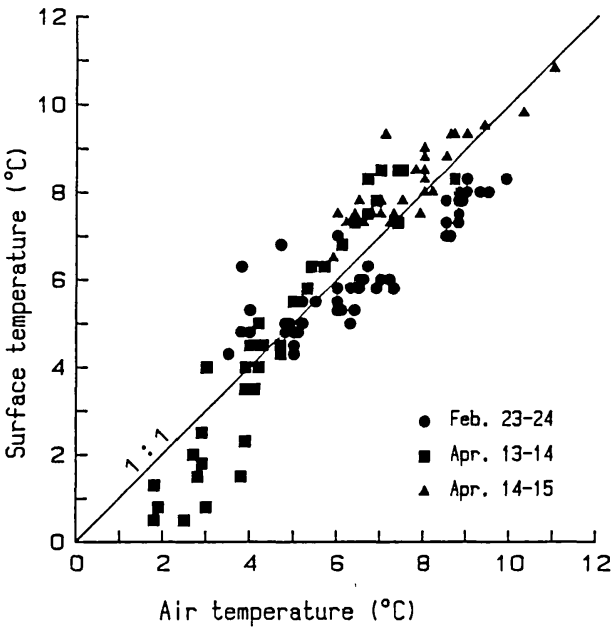

Fig. 2. Relationship between air temperature at $4 \mathrm{~m}$ and surface temperature at $10 \mathrm{~m}$ derived from infrared thermometer.

が異なるためと考えられる。4月には接地逆転による冷 気層が厚く，高度が増すにつれ気温が上昇したてとによ り，Fig. 2 では葉温 >気温の関係が得られたと考えられ る。

傾斜地では一般風が弱い日であ斜面滑降風の発生によ り無風となることはまれであり，顕熱交換が行なわれや すいととなどを考慮すると，傾斜地の夜間の気温と葉温 が極めて大きな温度差を示すことは少ないと考えられる。

(2) 斜面温暖帯の発達事例

1986 年 12 月 5 6 日の熱映像から得られた大麻山北 斜面の樹木葉温の等值線図と風向，風速の観測例を Fig. 3 (A)，（B) 江示す。

まず最初に，葉温の時間変化について述べる。標高 $110 \mathrm{~m}$ 以上では $16 \sim 18$ 時に葉温が約 $1.5^{\circ} \mathrm{C}$ 低下したのに 対し， $110 \mathrm{~m}$ 以下では葉温の低下量がそれよりあ大きく, 標高 $65 \mathrm{~m}$ では $16 \sim 18$ 時に $5.2^{\circ} \mathrm{C}$ の低下であった。同時 間帯に斜面滑降風が吹いて打り，乙の滑降風によって低 標高の葉温が低下したと考えられる。つまり，18 時まで の滑降風は冷気流として作用したてとになる。

18 時以降は標高 $250 \mathrm{~m}$ 付近に温暖帯が形成された。 温暖帯以上の標高では冷却が停止し平衡状態となったが, 温暖帯以下では低標高の葉ほど長時間葉温の低下が続 き，また低下量も大きく，特に標高 $80 \mathrm{~m}$ 以下で葉温の 低下が大きかった。温暖帯を境にして上方では葉温の低 下が停止し，下方では葉温の低下が続いたのは，斜面滑 降風の影響と考えられる。すなわち，標高 $250 \mathrm{~m}$ 以上で は斜面滑降風によって葉面と大気との顕熱交換が行なわ れ，熱収支的にバランスがとれて冷却が停止したのに対 

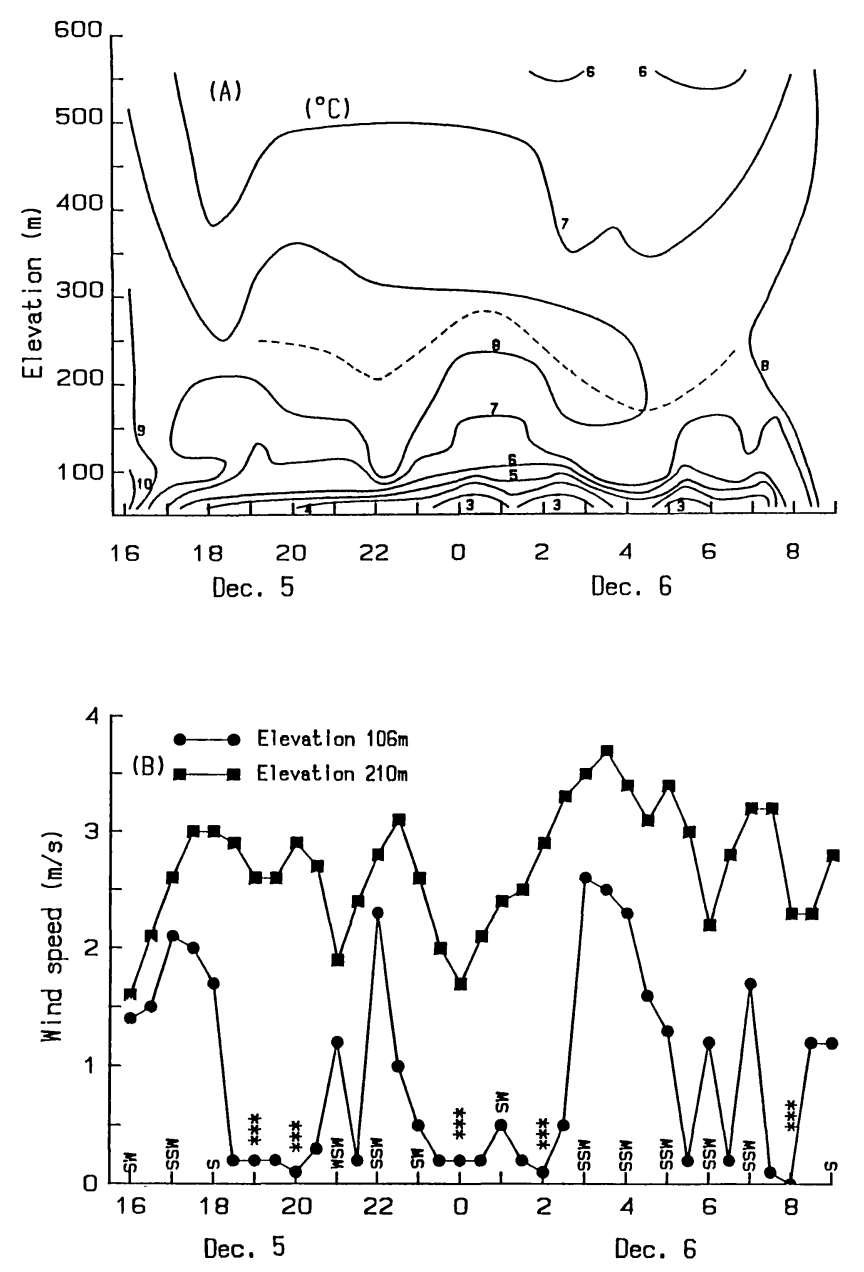

Fig. 3. (A) Isopleth of surface temperature at Mt. Osa on Dec. 5-6, 1986. The chain line is center of thermal belt.

(B) Variations of wind speed at two different heights $(106$ and $210 \mathrm{~m}$ ) and wind direction at the height of $106 \mathrm{~m}$. *** shows the unmeasureable wind direction because of the small wind speed below $0.2 \mathrm{~m} / \mathrm{s}$.

して，標高 $250 \mathrm{~m}$ 以下では逆転域に入ったてとにより滑 降風の侵入が抑えられ顕熱交換が減少し，また山麓域上 空への冷気の移流, 堆積により下向きの大気放射量が減 少したため葉温の低下が続いたと考えられる。 Magono et al., (1982) は盆地での観測から, 冷気の移流は日没 前後のわずかな時間でしかなく, その後, 冷気は盆地中 央部の上空へ移流, 堆積し，そての大気を冷却するにす ぎないと指摘しており，今回の観測で屯同様の傾向が認 められた。
温暖帯の中心から標高 $110 \mathrm{~m}$ までは, Fig. 3 (A)のように等温線の間隔が広く, 標高による温度勾配が小さいのに対し， $110 \mathrm{~m}$ 以下では等温線の間隔が狭く, 19 時 以降では逆転域が温度勾配の違いにより 2 域に区分される。下方の逆転域（以下，第 1 逆転域之よぶ）が形成されたのは, 標高 $110 \mathrm{~m}$ 以下の山麓域で鶴ヶ峰と磨臼山によ り開放度が小さく, 冷気が溜りやすく逃げ にくい条件にあるためと考えられる。

斜面温暖帯に近い標高 $210 \mathrm{~m}$ では風速 $1.5 \mathrm{~m} / \mathrm{s}$ 以上 (平均 $2.7 \mathrm{~m} / \mathrm{s}$ ) の風が常時吹 いているのに対し, 標高 $106 \mathrm{~m}$ 地点では風 は弱く, 平均風速 $0.8 \mathrm{~m} / \mathrm{s}$ で, $1.5 \mathrm{~m} / \mathrm{s}$ 以上 の風か間欠的に吹いている状態であった。 標高 $106 \mathrm{~m}$ と $210 \mathrm{~m}$ の風速差は 18 時以降明 瞭に現われた。乙の時刻は $106 \mathrm{~m}$ 地点が逆 転域に入った時刻と一致しており，逆転域 では滑降風の侵入が抑えられるととが判る。

標高 $210 \mathrm{~m}$ の風速が $3 \mathrm{~m} / \mathrm{s}$ を越えるよう な場合，標高 $106 \mathrm{~m}$ 地点に打いても $2 \mathrm{~m} / \mathrm{s}$ 以上の風が吹く場合が多かったが，標高 $210 \mathrm{~m}$ で $3 \mathrm{~m} / \mathrm{s}$ 以下の場合には $106 \mathrm{~m}$ 地点 では $0.5 \mathrm{~m} / \mathrm{s}$ 以下の風速であり, 滑降風が 逆転域㖊入するときと，しないときの風 速差は明瞭であった。逆転域では一般に滑 降風の侵入は妨げられるが，滑降風が強い 場合は逆転域に侵入することを示している。

風速之葉温の関係をみると, 風の強まっ た 22 時と $3 \sim 5$ 時には逆転域で葉温が上昇 し, 逆に風が弱まった時間帯には葉温が低 下した。乙のととから, 逆転域の葉に対し ては斜面滑降風は暖気流として作用すると 判断される。斜面滑降風は山地斜面上で放 射冷却した大気が同高度の自由大気より重 たいために斜面下方に向かって流れる風で あり，基本的には冷気流である。乙の冷気 流が逆転域に扔いて暖気流として作用するのは, 鈴木ら （1985）が示しているように，放射冷却条件下の傾斜地, 盆地に抢ける斜面下降気流が，冷気流としての冷却作用 よりあ本来の放射基づく冷却を緩和する作用の方が大 きいためである。今回の観測でむ，斜面滑降風は冷却を 緩和する方向に作用した。逆転域の植物は滑降風より低 温な冷気中にあり, また風速が弱いため放射冷却の影響 を強く受けている。乙の逆転域に滑降風が侵入するとと により，逆転域の破壊，気温の上昇，顕熱交換の促進な 
どによって葉温が上昇したと考えられる。

22 時と 3 時からの風速の増大時には, 温暖帯中心部 の葉温はほとんど上昇しなかった。それに対して, 逆転 域の葉温は上昇したが温暖帯中心部の葉温以上になるて とはなく，温暖帯中心部の葉温に近付く傾向があった。 標高 $90 \mathrm{~m}$ を境として, $90 \mathrm{~m}$ 以上では温暖帯中心部の葉 温とほぼ一致し, 温度差は $1{ }^{\circ} \mathrm{C}$ 以下であった。それに対 し, $90 \mathrm{~m}$ 以下では 22 時には葉温の上昇は認められず, $3 \sim 5$ 時では葉温は上昇したものの, 温暖帯中心部の葉 温より 1 4 ${ }^{\circ} \mathrm{C}$ 低かった。乙の現象は，逆転域に侵入し た滑降風の流れが標高 $90 \mathrm{~m}$ 付近で水平方向に変わった ためと考えられ, 強い冷気の中には滑降風は侵入しにく いと考えられる。

22 時と $3 \sim 5$ 時の風速を比較してみると，標高 210 $\mathrm{m}$ では 22 時 30 分に平均最大風速 $3.1 \mathrm{~m} / \mathrm{s}$, 最大瞬間風 速 $5.4 \mathrm{~m} / \mathrm{s}$ を記録したのに対し，3〜 5 時にはそれぞれ $3.7 \mathrm{~m} / \mathrm{s}, 6.4 \mathrm{~m} / \mathrm{s}$ を記録した。平均最大風速で $0.6 \mathrm{~m} / \mathrm{s}$ の差, 最大瞬間風速で $1.0 \mathrm{~m} / \mathrm{s}$ の差であった。同様に, 標高 $106 \mathrm{~m}$ 地点でも 22 時と 3 ～時の風速を比較してみ ると, 平均最大風速で $0.3 \mathrm{~m} / \mathrm{s}$ の差であった。 22 時と 3 〜 時の平均之瞬間の風速を比較した場合に明瞭な差が 認められないととから，逆転域の破壊には風の継続時間 が重要であることが判る。風速が同程度なら風の吹走時 間に比例して, 逆転域が上部から次第に破壊されるとと を示している。

次に，斜面温暖帯が形成された標高であるが，温暖帯 の中心は標高 $250 \pm 50 \mathrm{~m}$ の範囲に形成され，中心標高は 一定ではなく時間と共に変化した。温暖帯中心部の標高 は風速により左右され, 風が弱まると上昇し, 逆に風が 強まったときは低下した。

標高と最低温度の関係を Fig. 4 亿示す。最低温度が最 屯高い区域は標高 $250 \mathrm{~m}$ 付近に形成され，それ以上の標 高では $0.6 \sim 0.7^{\circ} \mathrm{C} / 100 \mathrm{~m}$ の割合で温度低下して抢り，乙 れは気温の湿潤断熱減率とほぼ等しい。温暖帯以下の標 高では急激に温度が低下し, 温暖帯の中心と標高 $65 \mathrm{~m}$ の温度差は 12 月 5 6 日の場合 $5.7^{\circ} \mathrm{C} ， 2$ 月 23〜24 日の 場合 $6.0^{\circ} \mathrm{C}$ であった。逆転域の最低表面温度の分布は 2 区域に分けられ，それぞれの区域内では標高に対してほ ぼ比例関係にあった。温度勾配は標高110１30 mに変化 する点が認められた。標高110 130 m以上では弱い温度 勾配であり，Fig.4 (A)，(B)において，それぞれ 1.4， $0.6^{\circ} \mathrm{C} / 100 \mathrm{~m}$ であり, $110 \sim 130 \mathrm{~m}$ 以下では $7.8,7.0^{\circ} \mathrm{C} /$ $100 \mathrm{~m}$ であった。地形, 気象条件によっては逆転域内の 表面温度低下の割合がいくつかに分けられることを示し ている。冷気湖の気温の鉛直分布から, 気温の変化の割 合が多層になるととが真木ら (1984) により示されてお

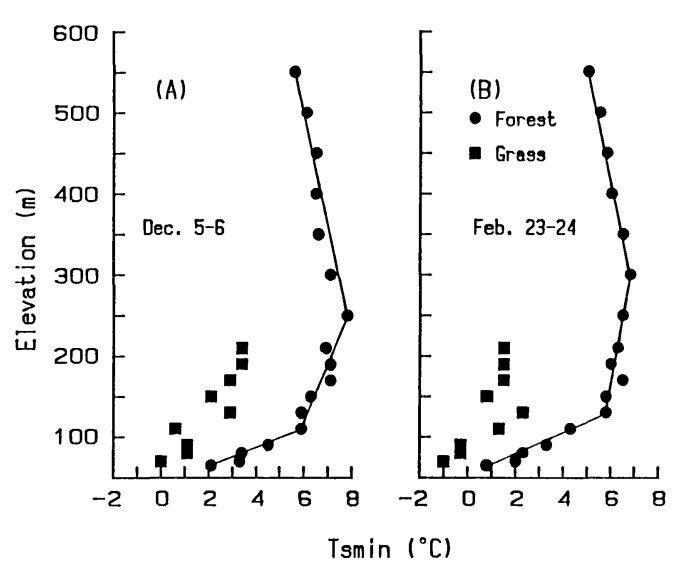

Fig. 4. The distribution of minimum surface temperatures of forest and grass on the slope of Mt. Osa.

(A): Dec. 5-6, 1986, (B): Feb. 23-24, 1987.

り，傾斜地の表面温度に対してあ類似の傾向があること が確かめられた。

（3）斜面温暖帯の未発達事例

斜面温暖帯が形成されなかった観測例として, 12 月 4 ～5 日の葉温の等值線図之風向, 風速を Fig. $5(\mathrm{~A})$, (B) に示す。

標高が高いほど温度が低下しているのが判る。風向は 斜面の最大傾斜方向之一致し, $1.5 \mathrm{~m} / \mathrm{s}$ 以上の風が常に吹 き，標高 $210 \mathrm{~m}$ と $106 \mathrm{~m}$ では後者の風速がやや大きい。 強い滑降風が常に低標高まで吹く場合には，逆転域は形 成されないか，あるいは形成されにくいと考えられる。 つまり, 強い斜面滑降風は逆転域を破壊する方向に作用 する。このととは 12月5〜6日の観測における, 強い滑 降風による逆転域の破壊作用之一致する。しかし，逆転 域が形成されなかったために滑降風が低標高まで吹いた と考えることあでき，今後因果関係を明確にする必要が ある。

一般に，逆転域が形成されないのは，放射冷却が弱い か，一般風が強いことが考えられる。しかし，逆転域が 発生しなかった 12 月 4〜 5 日逆転域が発達した 12 月 5〜6日について総合気象観測露場における夜間の放射 収支を比較すると $-2.4 \mathrm{MJ} / \mathrm{night}, \quad-1.5 \mathrm{MJ} / \mathrm{night}$ で あり，むしろ逆転域が発生しなかった日の方が放射冷却 は強かった。また，両日とも斜面滑降風が卓越したてと から，一般風は弱かったと考えられる。12月 4 5 日の 観測結果はかなり特異的な例と考えられるが，逆転域の 形成，消失に斜面滑降風の影響が大きいととが判る。今 後, 逆転域と斜面滑降風などの関係についてよりいっそ 

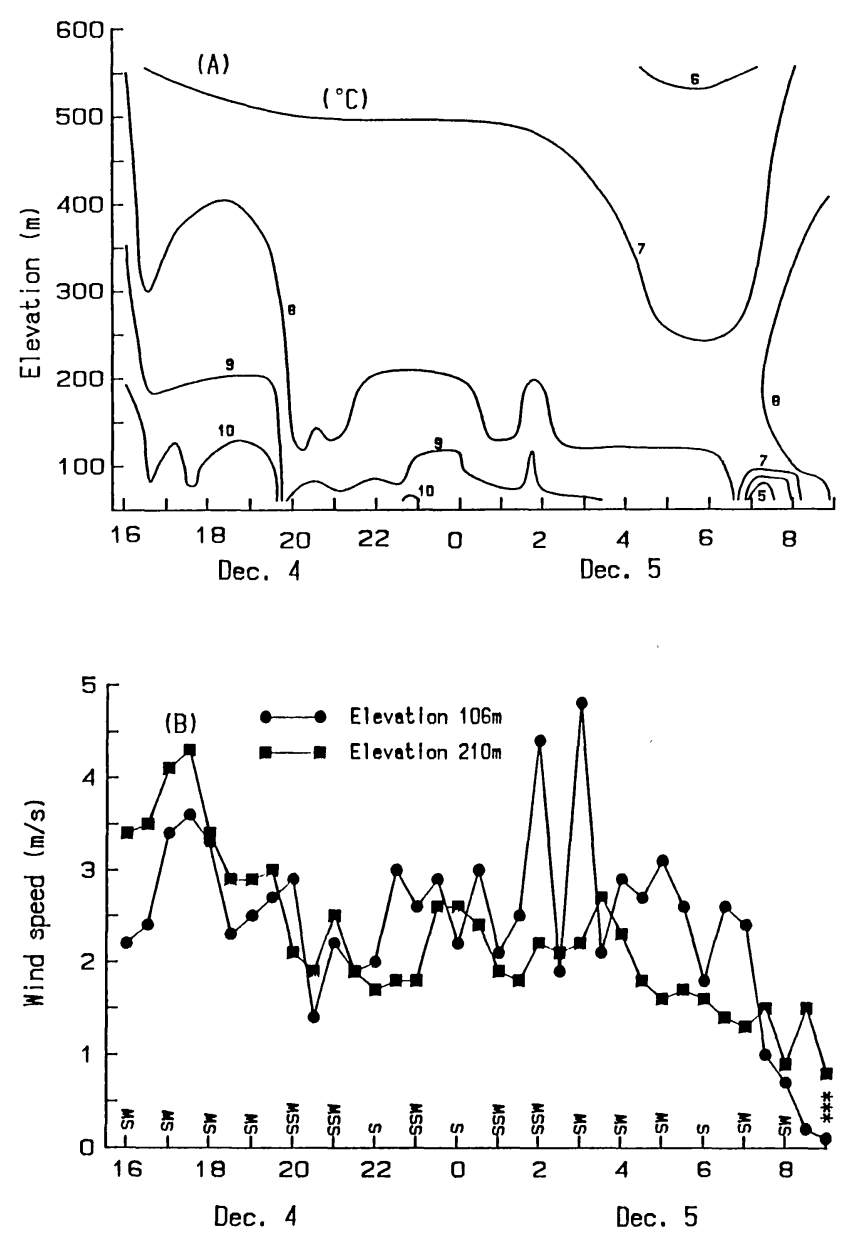

Fig. 5. (A) Isopleth of surface temperature at Mt. Osa on Dec. 4-5, 1986.

(B) Variations of wind speed at two different heights (106 and $210 \mathrm{~m})$ and wind direction at the height of $106 \mathrm{~m}$.

うの観測が必要である。

また，斜面温暖帯が極めて弱い事例として 4 月 14〜 15 日の観測があげられる。夜間は一晚中薄雲が観測さ れた。標高 $210 \mathrm{~m}$ 以下が逆転域となり，標高 $210 \mathrm{~m}$ と $65 \mathrm{~m}$ の最低温度の差は $1.3^{\circ} \mathrm{C}$ であった。標高 $100 \mathrm{~m}$ 地点 の夜間の平均風速は $1.5 \mathrm{~m} / \mathrm{s}$ であり, Fig. 3 (B) の 106 $\mathrm{m}$ 地点の風速変化之同様滑降風が侵入したときと, 侵 入できないときの風速差はかなり明瞭であった。標高 $100 \mathrm{~m}$ の葉温と風速を比較してみると正の相関が認めら れた。また, 風速増大時の葉温上昇が低標高にまで認め られ，12月 5 6 日の観測で，第 1 逆転域の葉温上昇に はある程度の滑降風の風速と, 吹走時間が必要であった ことと比較すると, 弱い逆転であれば滑降風は容易に逆
転域に侵入可能で，短時間の風速増大によ っても低標高まで葉温上昇をあたらすと考 えられる。

\section{（4）斜面滑降風の特徵}

斜面滑降風の特徵として, 風速と気温の 鉛直分布について述べる。

2月 23〜24 日における標高 $100 \mathrm{~m}$ 地点 の風速の分布型を $\mathrm{A}$ (風速の極大が高度 4 $\mathrm{m}$ 以上の場合), $\mathrm{B}$ (風速の極大が $2 \mathrm{~m}$ ない し $3 \mathrm{~m}$ の場合)， $\mathrm{C}$ (風速の極大が $0.5 \mathrm{~m}$ いし $1 \mathrm{~m}$ の場合）の三つに分類し, 風速と の関係をTable 1 亿示す。表に示すように, 風速 $2 \mathrm{~m} / \mathrm{s}$ 以上の場合はほとんど $\mathrm{A} タ イ$

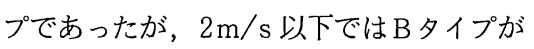
増加し, 風速の極大は低高度に移って 2 $3 \mathrm{~m}$ 高に現われた。風速が $1 \mathrm{~m} / \mathrm{s}$ 以下で はほとんどCタイプで風速の極大は 0.5 $1 \mathrm{~m}$ 高に出現した。 4 月 13〜15日にあ斜 面滑降風が吹いたが, 1〜2m/s の風速が 多かったためにほとんどBタイプであった。 また，斜面の最大傾斜方向の風向を持たな

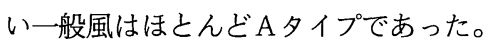

気温の鉛直分布に関しては 2 月の場合, 0.5 $1 \mathrm{~m}$ 高の気温差は約 $3{ }^{\circ} \mathrm{C}$ で極めて大き な接地逆転を示し，3〜 $4 \mathrm{~m}$ 高の気温差は $0.2^{\circ} \mathrm{C}$ 以下で, 低高度で気温差が大きかっ た。乙れは, 風速が $1 \mathrm{~m} / \mathrm{s}$ 以下の場合が 多く, 乱れが小さく上下間の混合が起とり にくいためと考えられる。4月のデータに 関しては 1〜 $4 \mathrm{~m}$ 高で 2 $3{ }^{\circ} \mathrm{C}$ の気温差で, 高度に対してほぼ直線的に気温が上昇し た。また, 一般風が吹くと気温差は小さく なった。

Table 1. Relation between the wind speed and the types of wind profile.

A: logarithmic profile, B: maximum at the middle region $(2-3 \mathrm{~m})$ of the profile, and $\mathrm{C}$ : maximum at the lower region $(0.5-1 \mathrm{~m})$ of the profile.

\begin{tabular}{|c|c|c|c|}
\hline Type & A & B & C \\
\hline Wind speed (m/s) & & & \\
\hline $0 \sim 1$ & 2 & 7 & 48 \\
\hline $1 \sim 2$ & 20 & 24 & 6 \\
\hline $2 \sim 3$ & 12 & 1 & 0 \\
\hline $3 \sim$ & 12 & 0 & 0 \\
\hline
\end{tabular}


2 月のデータに関して, 逆転域の風速と気温の関係を 各高度で調べると強い正の相関 $(r>0.8)$ が認められた。

2 月および 4 月の観測期間中, 標高 $65 \mathrm{~m}$ 地点の風速 は22〜24 時を境にして， $100 \mathrm{~m}$ 地点の風速とは相関を 持たなくなり，0.2〜 $0.6 \mathrm{~m} / \mathrm{s}$ の風速となった。逆転域の 下層では斜面滑降風とは関係を持たない独自の循環風が 形成されていると考えられる。

\section{（5）逆転域の鉛直構造とその時間変化}

逆転域の地上 $10 \mathrm{~m}$ までの鉛直構造について, 逆転域 の発生, 発達が比較的短時間に, しかも明瞭に観測でき た2月 23 日の観測データを用いて説明する。

Fig. 6 は標高 $210 \mathrm{~m}$ から $70 \mathrm{~m}$ までの牧草と樹木の両 方が生育している部分で, 高さの異なる牧草と樹木の表 面温度の差から, 気温分布の断面の様子を推定したもの である。牧草の表面温度は地表面近くの気温, 樹木の表 面温度は約 $10 \mathrm{~m}$ 高の気温 と等しいと仮定し, 等温線は 以上 2 高度の測定值から推定して求めた。位置関係は Fig. 1 亿扔いて大麻山北斜面を東方向から眺めたあので ある。(A) 逆転域発生前, (B) 逆転域発生直後, (C) 逆 転域発達後の図を示す。

逆転域発生前は, 斜面中腹から山麓まで樹木む牧草あ 同様な温度分布を示した。同標高の牧草の温度は樹木上 部の温度より約 $2^{\circ} \mathrm{C}$ 低く, 接地逆転が起てっている可能 性を示している。同時刻の標高 $100 \mathrm{~m}$ の測定点でも, 高 度 $0.5 \sim 4 \mathrm{~m}$ で約 $2^{\circ} \mathrm{C}$ の気温差がある接地逆転がみられ，
高度が増すに従い風速も増大した。標高 $100 \mathrm{~m}$ 地点の風 速は地上 $1 \mathrm{~m}$ 高で $2.0 \mathrm{~m} / \mathrm{s}$, 標高 $65 \mathrm{~m}$ の地上 $1 \mathrm{~m}$ 高にお いても $1.9 \mathrm{~m} / \mathrm{s}$ であり, 同程度であった。

21 時には標高 $100 \mathrm{~m}$ 以下の山麓域で冷却が進行し逆 転域が発生している。乙の時刻の標高 $100 \mathrm{~m}$ 地点の風速 の鉛直分布は $2 \mathrm{~m}$ 高に風速の極大が現われた。標高 65 $\mathrm{m}$ の風速は 22 時までは $100 \mathrm{~m}$ 地点の風速之同程度であ ったが， 22 時以降は $0.2 \sim 0.5 \mathrm{~m} / \mathrm{s}$ で, $100 \mathrm{~m}$ 地点にみら れた滑降風の侵入による風速の増大は認められなかっ た。

4 時には斜面上方に冷却が進行した。また, 地上 10 $\mathrm{m}$ までの接地逆転の強度は, 標高 $160 \mathrm{~m}$ 以上では約 $4{ }^{\circ} \mathrm{C}$ $/ 10 \mathrm{~m}$ であるのに対し，低標高では逆転強度が小さくな り, 標高 $70 \mathrm{~m}$ の逆転強度は $1.5^{\circ} \mathrm{C} / 10 \mathrm{~m}$ である。逆転域 の発達とと屯に山麓の逆転強度は中腹の逆転強度より相 対的に小さくなっている。乙の現象はFig. 4 の牧草之樹 木の最低温度の分布にも現れている。

播磨屋ら（1985）は, 盆地での係留気球などによる気 温の垂直分布観測により温位断面図を求め, 日没後は等 温位線は斜面に沿った分布であり, 冷却の進行につれ下 層から等温位線が水平になっていく過程を示している。 今回の観測では地上 $10 \mathrm{~m}$ 高までの温度情報しか得られ なかったが, 山麓から冷気が蓄積していき, ての冷気の 蓄積により等温線の傾きが緩くなる様子が観測できた。

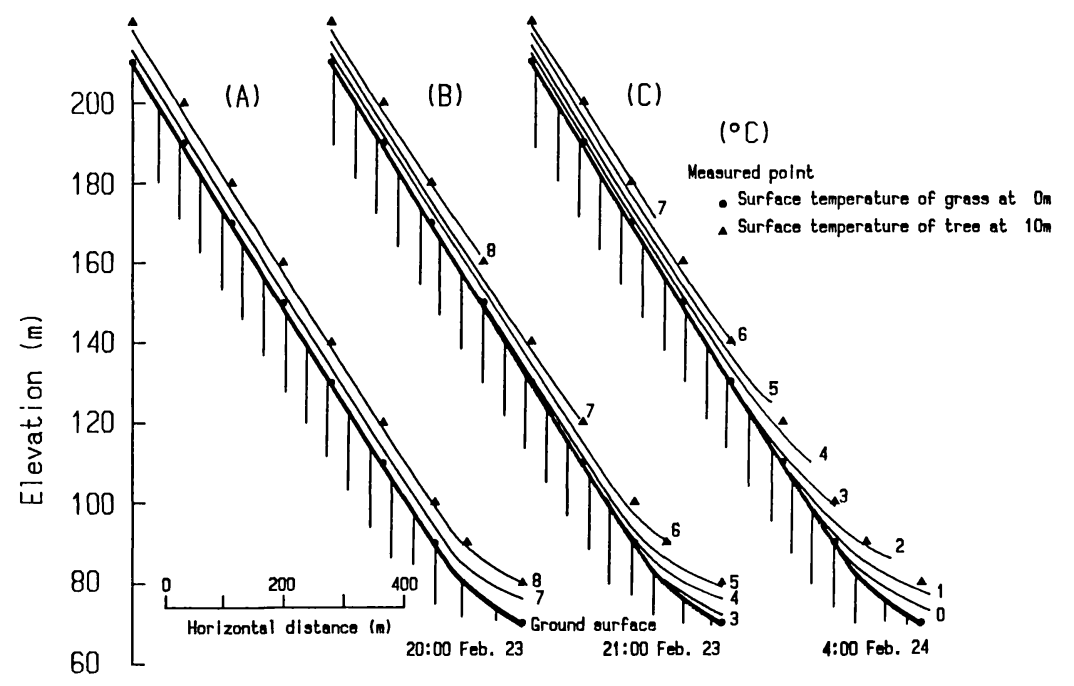

Fig. 6. Diagram of the development of inversion region inferred from surface temperatures on the slope. (A) Before the development of inversion region (20:00 Feb. 23), (B) At the beginning of the development (21:00 Feb. 23), (C) After the development (4:00 Feb. 24, 1987). 


\section{5. まと め}

放射熱解析装置を用いて, 局地気象および微気象レベ ルでの温度分布の特性解明に関する研究の一環として, 斜面に形成される温暖帯, 逆転域の分布を面的にとらえ, それらと斜面滑降風との関係を求めた。斜面滑降風が卓 越した日の観測から以下に示す結果を得た。

(1) 観測期間中, 斜面温暖帯の中心は標高 $250 \pm 50 \mathrm{~m}$ の範囲に形成された。温暖帯の中心は斜面滑降風が強ま った時には低標高に，弱まった時には高標高に移動す る。

（2）標高 $250 \mathrm{~m}$ 付近を境として，上方は気温莪減率に 従う順転域となり，下方は逆転域となった。逆転域は気 象, 地形条件により温度低下の割合がいくつかに分けら れ，今回の観測では 2 区域まで観測された。第 1 逆転域 の温度勾配は第 2 逆転域と比較して極めて急であり, 滑 降風が侵入しにくく逆転域が破壊されにくい。また，逆 転域の最低表面温度の分布は標高に対してほぼ比例関係 にある。

（3）逆転域では斜面滑降風は暖気流であり，葉に顕熱 を与え，葉温の上昇をあたらす。

（4）斜面滑降風は逆転域を破壊する方向で作用し, 破 壊の程度は風の強さと継続時間に比例する。また，逆転 が強いほど破壊されにくく，逆転が弱い場合には，1.5m /s 程度の間欠的な滑降風でむ低標高まで侵入して葉温 の上昇をむたらす。

\section{謝辞}

本研究を実施するに当たり, 四国農試農業気象研究室 中西松太郎主任研究官より貴重な 12 月の風向, 風速デ 一タを御提供いただいた。また, 四国農試草地畜産研究 室より長期間にわたり自記温度計を借用させていただい た。こてに厚く御礼申し上げる。なお，放射熱解析装置 および風向・風速計は場共用機械であり，乙れらの整備 に際して御尽力いただいた方々に心より感謝する。

\section{引用文献}

卜蔵建治・山下 洋・鈴木哲夫，1982：静止気象衛星
「ひまわり」のデー夕による冷害気象の研究，2.

昭和 55 年東北地方に発生した冷害時への適用例, 農 業気象, 37, 309-315.

Fuchs, M. and C. B. Tanner, 1966: Infrared thermometry of vegetation. Agron. J., 58, 597-601.

播磨屋敏生 - 真木雅之 - 菊池勝弘 - 谷口 巷 - 大平貴裕 - 吉弘雅士, 1985 ：北海道赤井川盆地に打ける夜間冷 却の観測, 北海道大学地球物理学研究報告, 45,29 -41 .

Heilman, J. L. and Moore, D. G., 1980: Thermography for estimating near-surface soil moisture under developing crop canopies. J. Appl. Meteor., 19, 324-328.

石黒 悟, 1985 : 熱映像による土壌含磁量調査, 水之土, 62, 29-32.

川島茂人, 1986: 航空機 MS S データによる地表面熱収 支分布の評価，天気， 33，333-344.

小林 守, 1979: 熱映像による筑波山の温暖帯の測定, 天気， 26, 161-166.

近藤純正, 1982 : 複雑地形に打ける夜間冷却 一研究の 指針一, 天気, 29, 935-949.

Magono, C., C. Nakamura and Y. Yoshida, 1982: Nacturnal cooling of Moshiri basin, Hokkaido in midwinter. J. Meteor. Soc. Japan., 60, 1106-1116.

真木雅之・播磨屋敏生・菊池勝弘・谷口 恭・堀江成人 1984 : 盆地污打りる夜間冷却過程, 北海道大学地球物 理学研究報告, 43, 17-29.

真木太一・黒瀬義孝, 1987: 赤外線放射温度計の局地気 象観測への応用，農業気象，43，233-237.

鈴木義則・山本 薰・青木正敏, 1985 ：暖地の霜害，寒 害之地形気象 (5) 斜面下降風之夜間放射冷却, 昭和 60 年度日本農業気象学会全国大会講演要旨, 24-25.

田中夕美子 - 石城謙吉・藤原滉一郎・小林大二，1982： 台地之谷すじの夜間冷却について（1）谷扔よび谷横 斜面の冷却過程，農業気象，38，245-251.

谷宏・堀口郁夫・元木敏博, 1984：農業気像に打け る人工衛星データの利用に関する研究 - GMS（ひま わり）赤外デー夕による地表面温度と AMeDAS 気温 との関係一, 農業気象, 40, 111-117.

鳥谷 均, 1985: 長野県菅平盆地における冷気湖の形成 之冷気流, 地理学評論, 58, 67-79. 


\section{Summary}

In order to study the process of the formation of the thermal belt (warm area in the middle of mountain) and the relationship between inversion region and katabatic wind, the micrometeorological observations and thermal image analysis of the northern slope of Mt. Osa were carried out. The remarkable development of thermal belt was found on the slope.

The results of the observations were summarized as follows:

(1) During the observation period, the center of thermal belt formed at the height of $250 \pm 50 \mathrm{~m}$ above the sea level. When katabatic wind was strong, the center of thermal belt moved to the lower part of the mountain. On the other hand, when the wind was weak, it moved to the upper part.

(2) When inversion region developed in this observation period, three regions were distinguished on the slope. In upper region, surface temperature fell with elevation. Middle (second inversion region) and lower region (first inversion region) were inversion regions. In each region, minimum surface temperature is proportional to the elevation. On the lower region, rate of minimum surface temperature decrease is higher than in the middle region. Boundary of the inversion regions was found at the height of $110-130 \mathrm{~m}$.

(3) The surface of the inversion region was warmed by the katabatic wind.

(4) The katabatic wind usually penetrated into the inversion region. Higher wind speed and longer period of wind promoted the penetration. 